\title{
Black fly (Diptera:Simuliidae) larvae body size variation along an altitude gradient in the Itatiaia National Park, Brazil
}

\author{
Biange Maria Cezário de Carvalho, Raquel leite Wainfas

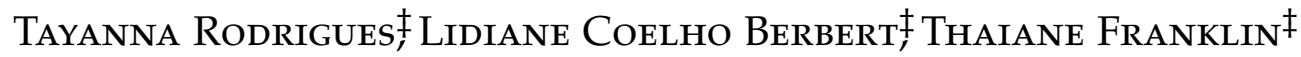 \\ Ivyn Karla Lima-de-Sousa $\ddagger$ Ronaldo Figueiró ${ }^{\ddagger *}$ \\ ronaldofigueiro@gmail.com
}

\begin{abstract}
Resumo
De acordo com a Regra de Bergmann, os indivíduos que habitam altitudes mais elevadas tendem a ser maiores na massa corporal ou tamanho, quando comparados com indivíduos do mesmo taxon que habitam lugares com altitudes mais baixas. Simulídeos são insetos de grande importância médica e veterinária, devido ao seu hábito hematófago tornando-se objeto de estudos a respeito de sua bionomia, ecologia e taxonomia. Estudos que abordem a influência do gradiente de altitude na morfologia dos Diptera: larvas Simuliidae são escassos na literatura, portanto, este estudo teve como objetivo investigar a influência do gradiente de altitude na morfologia dos Diptera: larvas Simullidae no Parque Nacional do Itatiaia, RJ, e assim, verificar se a Regra de Bergmann é aplicável a estes organismos. Imaturos de simulídeos foram coletados em quatro sítios durante os períodos de março e maio de 2013. Em cada sítio 30 larvas foram medidas, e estes comprimentos foram posteriormente comparados entre si através de Kruskal-Wallis, encontrando diferença significativa $(\mathrm{P}<0,05)$ entre os sítios em altitudes mais baixas em relação aos de altitudes mais elevadas, algo que foi corroborado através de uma análise de cluster. A altitude foi relacionada ao tamanho larvar através de uma regressão linear, demonstrando uma correlação positiva entre as variáveis, corroborando a regra de Bergmann para simulídeos. .
\end{abstract}

Palavras Chave: Regra de Bergmann, Simulídeos, Parque Nacional do Itatiaia.

Black fly larvae variation in an altitude gradient

\begin{abstract}
According to Bergmann's Rule, individuals who inhabit higher altitudes tend to be larger in body mass or size, when compared with individuals of the same taxon who inhabit lower altitude places. Black flies are insects of great medical and veterinary importance due to its blood-sucking habit, becoming subject of studies regarding its bionomics, ecology and taxonomy. Studies approaching the influence of the altitude gradient in the morphology of Diptera: Simuliidae larvae are scarce in the literature, therefore, this study aimed to investigate the influence of altitude gradient in the morphology of Diptera: Simullidae larvae in Itatiaia National Park, RJ, and thus verify if Bergmann's Rule is applicable to these organisms. Black fly larvae were sampled from four sites

\footnotetext{
*UNIFOA - Centro Universitário de Volta Redonda, Volta Redonda/RJ1

${ }^{\dagger}$ Laboratório de Simulídeos e Oncocercose - FIOCruz - Fundação Oswaldo Cruz

łLaboratório de Biotecnologia Ambiental / UEZO- Fundação Centro Universitário Estadual da Zona Oeste, Rio de
} Janeiro/RJ
\end{abstract}


during periods of March and May 2013. From each site 30 larvae were measured, and these lengths were later compared between sites using Kruskal-Wallis, which showed a significant difference $(\mathrm{P}<.05)$ among sites from lower altitudes in relation to those of higher elevations, what was corroborated using a cluster analysis. The altitude was related to larval size using a linear regression, showing a positive correlation between these variables, thus corroborating Bergmann's rule for Black flies.

key words: Bergmann's Rule, simuliid, Itatiaia National Park.

\section{INTRODUCTION}

A ccording to Bergmann's Rule, individuals who inhabit higher altitudes tend to be larger in body mass or size, when compared with specimens of the same organisms that inhabit places of lower altitudes. The colder the climate, the body size of the animals tends to be larger, but in regions of warmer climate the animals tend to be smaller (ASHTON, 2001; SHELOMI, 2012).

Laboratory studies support the idea that animals raised at lower temperatures grow up on a larger body size than those reared at higher temperatures. Indeed, evaluations indicate that this pattern is observed in diverse groups of organisms, including plants, animals, bacteria and protozoa (ANGILLETA \& DUNHAM, 2003).

The biogeographic patterns can be tested for multiple groups, such as groups with wide geographical and climatic distribution, as is the family Simuliidae. Since the discovery that populations of the same taxon distributed in different locations could vary in body shape, the relationship between geographic variation and the development of organisms came to be studied and analyzed (SHELOMI, 2012). Even though studies on black fly larvae morphology have often correlated larval size to flow conditions (CRAIG\& CHANCE, 1982; PALMER \& CRAIG, 2000; FIGUEIRÓ et al., 2015), there is a gap in the knowledge of the influence of an altitude gradient on black fly body size.

Black flies are insects of the order Diptera, suborder Nematocera, and family Simuliidae. These dipterans are distributed worldwide, except in Antarctica and in some islands tha thave no running water (CURRIE \& ADLER, 2008). The insect family Simuliidae is subdi- vided into two subfamilies: Parasimuliinae, found in the Nearctic region and Simuliinae, of cosmopolitan characteristics (ADLER \& CROSSKEY, 2015).

Currently the Simuliidae family comprises 2,219 species, being 2,204 living species and 15 fossil Adler \& Crosskey (2016).This insect family is widely distributed, extending from the tropics to the Arctic and Antarctic Circles (ARAUJO-COUTINHO et al., 2005; FIGUEIRÓ et al., 2006).

Due to their blood-sucking habit, black flies are prominent in human and veterinary medicine, becoming the focus of studies about their bionomics, ecology and taxonomy (ADLER \& CROSSKEY, 2015). Black flies hematophagous activity interferes on the quality of life and animal productivity, as well as their bites cause discomfort, some species of black flies are vectors of diseases and when in high incidences, tourism and farming are also affected. Some species of black flies are vectors of the nematode Onchocerca volvulus Leuckart, 1893, which damages the skin and can produce eye injuries that often lead to blindness. The literature also suggests that Endemic Pemphigus Foliaceous or "fogo selvagem", which is a self-immune disease, is triggered by the bite of black flies (EATON et al.,1998).

The unique features of the biology and ecology of black flies explains the occurrence of several populations, forming communities of different species along the rivers and streams. The distribution and abundance of species along a water shed are influenced by several factors, such as the size and flow of water courses, substrate availability for the fixation of the immature stages, substances dissolved in water, food availability, composition of the riparian forest, altitude and anthropogenic inter- 
ference in the neighboring areas of the breeding sites (HAMADA \& MCCREADIE, 1999; KUVANGKADILOK et al., 1999, FIGUEIRÓ et al., 2008, 2012, 2014, BERTAZO \& FIGUEIRÓ, 2012,DOCILE et al., 2015).

This study aimed to investigate the influence of the altitude gradient in the morphology of Diptera: Simullidae larvae in the Itatiaia National Park, RJ, and thus verify if Bergmann's Rule is applicable to these organisms.

\section{Methods}

\section{Study area}

The Itatiaia National Park was the first national park created in Brazil, founded in June 1937 it is located in the southeast of the State of Rio de Janeiro. Situated in the Serra da Mantiqueira, the Itatiaia National Park covers the municipalities of Resende and Itatiaia, in the State of Rio de Janeiro, Bocaina de Minas and Itamonte in Minas Gerais, whichare approximately $60 \%$ of its territory. Situated between the coordinates $44^{\circ} 34-44^{\circ} 42 \mathrm{~W}$ and $22^{\circ} 16$ $22^{\circ} 28 \mathrm{~S}$, it is characterized by mountains and rocky elevations, with altitudes ranging from 540m.a.s.l. to 2.791m.a.s.l. in its peak, the Pico das Agulhas Negras. The Park is subdivided in the lower end (lowlands) Itatiaia Park, where the visitor center is located, and the upper end (highlands), where the Agulhas Negras peak is located.

\section{Sampling sites}

The collection of immature black flies was performed in four sites in different altitudes (Figure 1, Table 1).
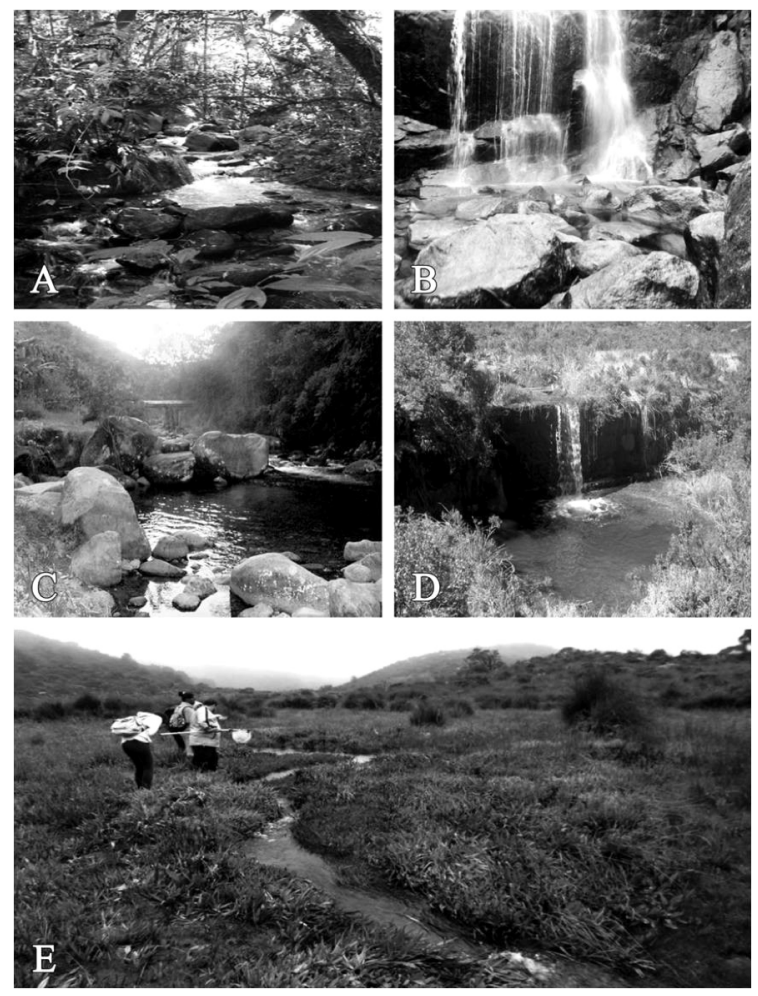

Figure 1: Sampling sites where larvae were taken from: $T Q(A) ; V N(B) ; C B U(C) ; B L(D) ; C B S(E)$. See table 1 for the abbreviations.

Table 1: Mean Lengths and standard deviations of black fly larvae in each site.

\begin{tabular}{cccc}
\hline \hline River & Site & Abbreviation & Altitude \\
Taquaral & Taquaral & TQ & 874 \\
Véu da Noiva & Véu da Noiva & VN & 1100 \\
Brejo da Lapa & Brejo da Lapa & BL & 2175 \\
Campo Belo & Urban & CBU & 505 \\
Campo Belo & Source & CBS & 2500 \\
\hline \hline
\end{tabular}




\section{Collecting and Sorting of Larvae}

Samplings were held in March 2013 in CBS and BL sites, located in the upper part of the Park. In May 2013 a new collection in the lower part of the Park, in CBU, TQ and VN was performed. The larvae of Simuliidae were manually collected, caught up directly from the riffle litter then placed in labeled plastic bags containing $70 \%$ ethanol for preservation and hydration of larvae for transport to the laboratory.

The material was taken to the Laboratório de Zoologia of the Centro Universitário de Volta Redonda (UniFOA), where it was screened. After sorting, the material was analyzed at the Laboratório de Biotecnologia Ambiental from the Centro Universitário Estadual da Zona Oeste (UEZO). Groups of 30 larvae from each collection point were randomly selected, and then were photographed with the aid of a stereoscopic microscope connected to a Moticam 5 image capture system. The length from the base of the head capsule to the posterior end of the body of the larvae was measured by their images captured with the assistance of CMEIAS 1.28 - IT software.

\section{Statistical analysis}

Larvae sizes were tested for normality using the Shapiro-Wilk test, and subsequently submitted to linear regression, Kruskal-Wallis and a Cluster Analysis based in the Bray-Curtis similarity index.

\section{Results AND Discussion}

A total of 150 larvae were analyzed, respectively 30 larvae of each site, summing up five sampling sites. The hypothesis that Simuliidae larvae of higher altitudes should be larger was corroborated by the Kruskal-Wallis analysis, in which the sampling sites that were located at higher altitudes (Campo Belo (source) and Brejo da Lapa) had individuals that had significantly greater size $(p<0.05)$ than those from lower altitudes (Campo Belo - urban, Taquaral and Véu da Noiva), as Bergmann's Rule predicts (Figure 2). The linear regression was significant $(\mathrm{P}<.001, \mathrm{R} 2=0.34)$, showing a positive correlation between altitude and larvae body length (Figure 3).

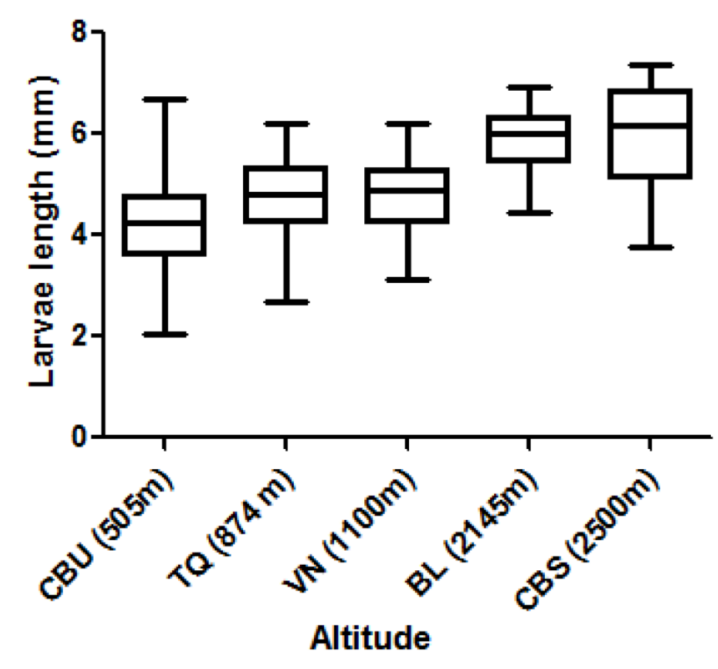

Figure 2: Mean larval length (Y) opposed to altitude (X) indicating the trend towards larger lengths at higher sites and significant differences $(p<.05)$ between the lowlands (CBU, TQ,VN) and the highlands (BL, CBS).

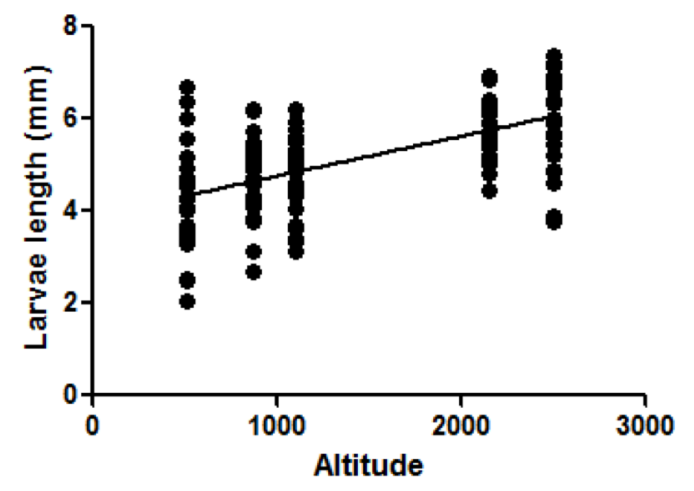

Figure 3: Linear regression $(F=79.59, \quad P<.001$, $R 2=0.3497$ ) pointing towards a positive correlation between altitude and larval body length. 
The similarity in body length of the larvae between the collection sites was assessed by means of Cluster analysis (Fig. 4), which grouped the sites of the highland (CBS and $\mathrm{CBU}$ ) in the same branch, and grouped in the other branch sites in the lowland (TQ and VN). The CBU site, although located in the lower part, was in an individual branch, indicating a comparatively lower similarity in relation to the other sites (even though it showed an elevated similarity of $85 \%$ ). Such fact maybe due to the major anthropogenic pressures from human activities, as it is located in an urban area, outside of the limits of the Park.

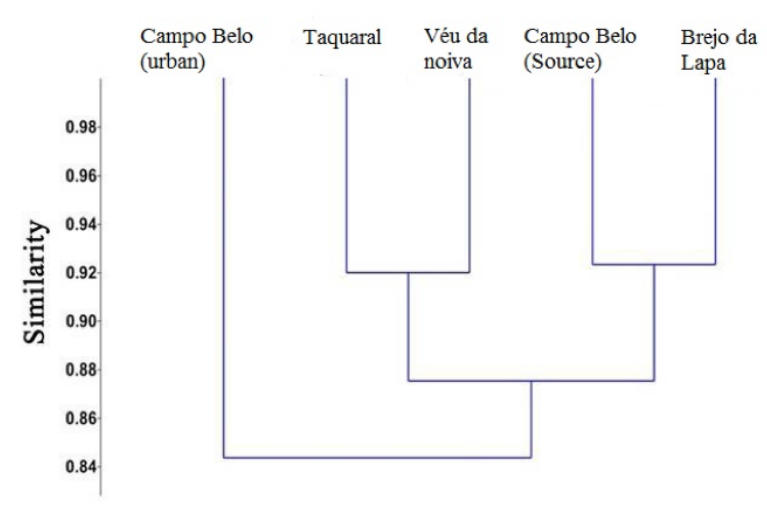

Figure 4: Cluster analysis based on Bray-Curtis index applied to the body length of the larvae, indicating the separation of the high places of the Itatiaia National Park (nascent of Campo Belo river and Brejo da Lapa) of those on the lower part (Taquaral and Véu da Noiva).On the other hand, the Campo Belo river - urban part, was the more dissimilar to the others (even though still 85\% similar).

This pattern was also described in a study of Lutzomyia intermedia (Lutz and Neiva 1912) by Marcondes et al (1999) in which it was observed the influence of altitude on the sizes of some structures in insects captured at higher locations, also following the predictions of the Bergmann's rule. Another study that also approached the relationship between body size and the altitude gradient was Angilleta and Dunham(2003) in which animals raised at lower temperatures grew more.

Thus, the present study indicates a relationship between the gradient of altitude and body size of larvae of Diptera: Simullidae in Itatiaia National Park, RJ, since the collection sites located at higher altitudes (CBS and BL) had higher body when compared to larvae collected at low altitudes (CBU, TQ and VN), suggesting Bergmann's Rule can be applied to black fly larvae. The study of phenomena related to altitude gradients, such as the Bergmann's Rule are of extreme relevance as they provide insights of possible effects of climate change.

\section{ACKNOWLEDGMENTS}

To André Resende de Senna and Nathane Medeiros, for their help in the field. To the staff of Laboratório de Biotecnologia Ambiental UEZO. To Fundação de Amparo à Pesquisa do Estado do Rio de Janeiro (FAPERJ) for the financial support.

\section{REFERENCES}

ADLER, P.H; CROSSKEY, R.W. World blackflies (DIPTERA: SIMULIIDAE): Acomprehensive revision of the taxonomic and geographical inventory. em: http://www.clemson.edu/cafls/biomia/ pdfs/blackflyinventory.pdf, 2016

ANGILLETTA Jr, M.J. ; DUNHAM, A.R. The temperature-size rule in ectotherms: simple evolutionary explanations may not be general. TheAmerican Naturalist,v.162, n. 3, p.332-342, 2003.

ARAÚJO-COUTINHO, C.J.P.C.; FIGUEIRÓ, R.; VIVIANI, A.P.; NASCIMENTO, E.S.; CAVADOS, C.F.G. A Bioassay Method for Black Flies (Diptera: Simuliidae) Using Larvicides. Neotropical Entomology, v. 34, p. 511513, 2005.

ASHTON, K.G. Are ecological and evolutionary rules being dismissed prematurely? Blackwell Science, v.7, p.289-295, 2001. 
BERTAZO, K., FIGUEIRÓ, R. Spatial Distribution of Black Fly (Diptera: Simuliidae) Immatures in a Water Current Velocity Gradient in Aracruz/ES, Brazil. Rev. de Cienc. da Vida, v.32, n.2, p.91-101, 2012.

CRAIG, D.A.; CHANCE, M.M. Filter feeding in larvae of Simuliidae (Diptera: Culicomorpha): aspects of functional morphology and hydrodynamics. Canadian Journal of Zoology, v.60, p.712-724, 1982.

CURRIE, D. ; ADLER, P. Global diversity of black flies (Diptera: Simuliidae) in freshwater. Hydrobiology,v.595, p.469 - 475, 2008.

DOCILE, T.; FIGUEIRÓ, R.; GIL-AZEVEDO, L.H.; NESSIMIAN, J.L. Water pollution and distribution of black fly larvae (Diptera: Simuliidae) in the Atlantic Forest, Brazil. Revista de Biologia Tropical. v.63, n.3, p.683693, 2015.

EATON, D.P. ; DIAZ, L.A.; HANS-FILHO, G.; DOS SANTOS,V.; AOKI, V.; FRIEDMAN, H.; RIVITTI,E.A. Comparison of Black fly species (Diptera: Simuliidae) on an amerindian reservationwith a high prevalence of fogo selvagem to neighboring disease free sites in the state of Mato Grosso do Sul, Brazil. Journal of Medical Entomology. v.35, p.120-131, 1998.

FIGUEIRÓ, R.; ARAÚJO-COUTINHO, C.J.P.C.; GIL-AZEVEDO, L.H.; NASCIMENTO, E.S.; MONTEIRO, R.F. Spatial and Temporal Distribution of Black flies (Diptera: Simuliidae) in the Itatiaia National Park, Brazil. Neotropical Entomology, v.35, p.542550, 2006.

FIGUEIRÓ, R ; NASCIMENTO, E.S. ; GILAZEVEDO, L.H. ; MAIA-HERZOG, M. ; MONTEIRO, R.F. Local distribution of blackfly (Diptera, Simuliidae) larvae in twoadjacentstreams: the role of water current velocity in the diversity of blackfly larvae. Revista Brasileira de Entomologia v.52, n.5, p.452-454, 2008.
FIGUEIRÓ, R.,; GIL-AZEVEDO, L. H. ; MAIAHERZOG, M. ; MONTEIRO, R.F. Diversity and microdistribution of black fly (Diptera: Simuliidae) assemblages in the tropical savanna streams of the Brazilian cerrado. Memórias do Instituto Oswaldo Cruz, v.107, n.3, p.362-369, 2012.

FIGUEIRÓ, R.; MAIA-HERZOG, M.; GILAZEVEDO, L.H.; MONTEIRO, R.F. Seasonal variation in black fly (Diptera: Simuliidae) taxocenoses from the Brazilian Savannah (Tocantins, Brasil). Journal of Vector Ecology, v.39, p.321-327, 2014.

FIGUEIRÓ, R.; CALVET, A.; GIL-AZEVEDO, L.H.; DOCILE, T.N.; MONTEIRO, R.F.; MAIA-HERZOG, M. Evidence of phenotypic plasticity of larvae of Simulium subpallidum Lutz in different streams from the Brazilian Cerrado. Revista Brasileira de Entomologia., v.59, p.30-33, 2015.

HAMADA, N.; McCREADIE, J.W. Environmental factors associated with the distribution of Simulium perflavum (Diptera: Simuliidae) among streams in Brazilian Amazonia. Hydrobiology, v.397, p. 71-78, 1990.

KUVANGKADILOK, C. ; BOONKEMTONG, C. ; PHAYUHASENA, S. Distribution of the larvae of blackflies (Diptera: Simuliidae) at doiinthanon national park, northern Thailand. The Southeast Asian Journal of Tropical Medicine and Public Health, v.30, n.2, p.328-337, 1999.

MARCONDES CB., LOZOVEI AL., FALQUETO A., BRAZIL RP., GALATI E., AGUIAR G. Influence of altitude, latitude and season of collection (Bergmann's Rule) on the dimensions of Lutzomyia intermedia (Lutz and Neiva, 1912) (Diptera, Psychodidae, Phlebotominae). Memórias do Instituto Oswaldo Cruz, v.94, n.5, p.693-700, 1999.

MCCREADIE J., COLBO MH. Spatial distribution patterns of larval cytotypes 
of the Simuliumnenustum/verecundum complex on the Avalon Peninsula, Newfoundland: Factors associated with cytotype abundance and composition. Canadian Journal of Zoology, v.70, p.1389-1396, 1992.

PALMER, RW., CRAIG DA. An ecological classification of primary labral fans of filterfeeding black fly (Diptera: Simuliidae) larvae. Canadian Journal of Zoology, v.78, p.199218, 2000.
ROSS, DH., MERRITT RW. Factors affecting larval black fly distributions and population dynamics. In: K. C. Kim and R. W. Merritt, R. W. (eds.): Black flies: Ecology, population management and annotated world list. The Pennsylvania State University, University Park, Pennsylvania, USA. 1987. p. 90-108.

SHELOMI, M. Where are we now? Bergmann's rule sensulato in Insects. Am. Natural., v.180, n.4, p.511-519, 2012. 